Милена Ивановић ${ }^{1}$

Филолошки факултет

Универзитета у Београду

https://doi.org/10.18485/mks_knsjkk.2017.ch9

\section{ПРИНЦИПИ ОРГАНИЗОВАҢА ГРАМАТИЧКОГ МАТЕРИЈАЛА У ПОЧЕТНОЈ НАСТАВИ ГРАМАТИКЕ УКРАЈИНСКОГ ЈЕЗИКА}

Учење страног језика има неколико аспеката. Један од њих је граматика: познавање граматичких облика и њихових функција неопходно је како за добро разумевање усменог или писменог говора, тако и за правилну формулацију исказа. Питања приступа настави граматике украјинског језика као страног, поготово у инословенској средини, нису била предмет ширег интересовања методичара. Циљ нашег рада је да представимо једну од могућности методичке организације граматичког материјала у настави украјинског језика на почетном нивоу. Реч је о таквој организацији материјала која се базира на функционалном принципу који обједињује семасиолошки и ономасиолошки приступ. Такав приступ подразумева упознавање студената са граматичким формама и њиховим основним функцијама, када се полази од форме ка значењу, на првој етапи учења украјинског језика, док се на другој етапи усвојени облици понављају и утврђују полазећи од комплекса различитих значења (значења места и правца, времена, објекта, адресата итд.) ка падежним облицима и предлошко-падежним конструкцијама који учествују у њиховом изражавању, уз увођење других средстава (прилози, заменице). Други битан принцип организације граматичког материјала јесте и основно методолошко начело „од лакшег ка тежем”. Ово начело у конкретном случају подразумева одбацивање како традиционалног редоследа учења падежа (номинатив - генитив - датив - акузатив - инструментал - локатив - вокатив) тако и оног који је уобичајен у новијим методикама и уџбеницима (номинатив - локатив - акузатив - генитив - инструментал - датив - вокатив) у циљу поступног управљања формама које студенти треба да усвоје.У таквом редоследу (номинатив - локатив - инструментал - датив - генитив - акузатив - вокатив) генитив је, на пример, премда облик са великим бројем најразличитијих функција, а с обзиром на већи избор наставака и сложенија правила њихове употребе, представљен тек после датива, облика са знатно мањим бројем функција. Акузатив је пак, иако један од централних падежа украјинског падежног система, иако релативно лак за усвајање за говорнике српског језика, обрађен тек након генитива, јер се код већине именица његов облик подудара управо са генитивом или номинативом. Трећи принцип организације граматичког ма-

\footnotetext{
${ }^{1}$ ivanovic.milena@gmail.com
}

теријала можемо одредити као комуникативни. Настава граматике неодвојива је од учења лексике, а комуникативна оријентација наставе подразумева обраћање пажње студената не само не облике, не само на њихово значење, већ и на употребу усвојених облика у комуникацији. Распоред граматичког материјала у том смислу мора пратити редоследувођења нове лексике и говорних тема које се обрађују у оквиру почетног курса савременог украјинског језика.

Кључне речи: граматика, функционални принцип, принцип „од лакшег ка тежем", комуникативни принцип, лексика.

Украјински језик предаје се на Филолошком факултету Универзитета у Београду од 1991. године као други словенски језик, а од 2002. као главни језик. Недостатак уџбеника као и методичких приручника ${ }^{2}$ за наставу украјинског језика као страног наметнуо је потребу разраде сопствене концепције организације и презентације градива.

Дуго година украјински језик предаван је у оквиру једног курса који је обухватао теоријска предавања и практична вежбања. Увођењем болоњског система студирања дошло је и до измена, које су подразумевале раздвајање наставе језика у два курса - Украјински језик (1-8) и Савремени украјински језик (1-8, односно 1-4 за оне који украјински уче као други језик). Предмет Украјински језик (УЈ), са фондом од два часа недељно, теоријски је усмерен, а језичке чињенице презентују се и изучавају по језичким нивоима: фонетском (УЈ 1 и 2), морфолошком (УЈ 3 и 4), творбеном (УЈ5), лексичком (УЈ6) и синтаксичком (УЈ 7 и 8). Предмет Савремени украјински језик (СУ) усмерен је практично, за њега је предвиђено 8 часова недељно, и то по два за наставу граматике и правописа и четири за тзв. говорна вежбања, а језичке чињенице презентују се и изучавају по нивоима Заједничког европског оквира за живе језике (CEFR) од нивоа A1 до нивоа C1.

Граматика се, дакле, изучава у оквиру оба курса, али са различитим циљевима и са различитих позиција. Циљ предмета

\footnotetext{
${ }^{2}$ Настава граматике украјинског језика као страног, поготово у инословенској средини, тек у последње време привлачи пажњу методичара. Рецимо, у зборнику научних радова Теорія і практика викладання української мови як іноземної, који излази једном годишње од 2006. године овим питањима посвећено је у просеку два до три чланка по броју, а они се махом тичу појединачних граматичких проблема у настави украјинског као страног.
} 
УЈ јесте теоријско познавање језичког система стандардног украјинског језика односно стицање систематизованих теоријских знања о сваком нивоу језика, као и навика компаративног и контрастивног проучавања украјинског и српског језика, док је циљ курса СУЈ усвајање и развијање језичких умења и вештина, стицање одговарајуће језичке компетенције. У оквиру оба курса граматика се предаје са позиција и системско-категоријалног и функционалног приступа, с тим што је у оквиру УЈ нагласак на првом, а у оквиру СУЈ на другом.

Настава граматике у оквиру предмета СУЈ базира се на програму чији су елементи граматички облици и структуре, с једне стране, и лексика којом се „попуњавају“ дате структуре у одређеним комуникативним ситуацијама. Приликом одабира граматичког материјала који ће бити обрађиван на почетном нивоу (предмет СУ 1 и 2, односно A1 ка А2 нивоу европског оквира) ослањали смо се на препоруке Навчальні мінімуми з украӥнської та російської мов для іноземців (Зайченко, Воробйова 1995) године, а затим и на стандарде Министарства просвете Украјине Загальноосвітній стандарт з української мови як іноземної (рівні: A1, $A 2$; $B$ 1, $B$ 2; C1) (Ніколаєва, Бондарєва и др. 2014, 2014а); организација одабраног материјала базира се на неколико принципа, о којима ће даље бити реч.

Методика наставе језика неодвојива је од науке о језику. То не значи само да се настава језика ослања на оне чињенице које је лингвистика описала и анализирала већ и да „усвајање граматичког аспекта треба да буде адекватно нивоу развијености савремене лингвистичке науке" (Кончаревич 2004: 148). За методику је посебно значајна функционална граматика, усмерена ка повезивању нивоа и обједињавању парадигматског и синтагматског аспекта, укључивању семантичког и комуникативног момента (Кончаревич 2004: 148; Мацюк 2007: 33). Функционални принцип организације градива у методици, као и функционална граматика обједињује у себи два приступа: семасиолошки (од форме ка садржају) и ономасиолошки (од садржаја ка форми). То подразумева упознавање студената са граматичким формама и њиховим основним функцијама, када се полази од форме ка значењу, на првој етапи учења украјинског језика. Реч је о хори- зонталној обради падежа, када се дају одабрана значења једног падежа, која се усваја на материјалу разних врста речи, а затим се уводи следећи падеж (Балыхина 2007: 101). На другој етапи усвојени облици се понављају и утврђују полазећи од комплекса различитих значења ка падженим и предлошко-падежним облицима који учествују у њиховом изражавању, уз увођење других средстава (прилози, заменице и сл.). Студенти на тај начин стичу не само граматичку већ и семантичку компетенцију.

Други битан принцип јесте комуникативни. Граматика у курсу СУЈ није сама себи циљ, већ је неопходна за правилно разумевање и продуковање говора, она је средство стицања практичних језичких вештина и умења. Примена комуникативног принципа у настави значи да су часови усмерени на граматику, али су чисто теоријска објашења сведена на минимум, да се дају основна, али не обавезно и сва правила образовања и употребе граматичких облика, те да се граматички материјал уводи тако да се одмах може укључити у говор. Примена овог принципа у организацији граматичког материјала значи пак да се градиво распоређује тако да прати редослед обрађивања говорних тема и лексичких јединица (номинатив: Мене звати Тарас; Я студент; Ми студенти, локатив: Я живу в Белграді; Я навчаюся на філологічному факультеті, инструментал: Я розмовляю українською мовою; Я займаюся спортом; Я цікавлюсь сучасною українською музикою, датив: Мені подобаються українські художні фільми; Мені двадиять років итд.). Води се рачуна о томе да различити елементи језика (фонетски, лексички, граматички) у говору наступају заједно (Балыхина 2007: 98). Лексичко-морфолошки материјал даје се на синтакичкој основи - предмет рада нису изоловане форме већ облици употребљени у реченици, говорним обрасцима, конкретним говорним ситуацијама. Уз то, студентима се обавезно скреће пажња на изговор наставака (рецимо асимилације у облицима датива и локатива книжці, дочці или промени повратних глагола смієшся, сміється) и њихово писање, то јест успоставља се веза са фонетским нивоом језика.

За организацију граматичког материјала веома су важни резултати контрастивних лингвистичких истраживања (Мацюк 2007: 32). Они одређују примену једног од основних методичких 
принципа „од лакшег ка тежем”: граматички материјал се градира према степену тежине тако што се најпре обрађују оне јединице које показују сличност у облицима и/или функционисању у украјинском и српском језику, како би се постигао позитиван трансфер. С друге стране, непрестано се указује на разлике између ова два језика како би се минимализовала интерференција. Поред достигнућа контрастивне лингвистике учење украјинског језика српским студентима, с обзиром на његову сродност са њиховим матерњим, могу олакшати и достигнућа компаративне лингвистике. Студенти, рецимо, лакше усвајају појаву непостојаних вокала $о$ и $е$, ако знају да они, као и српско непостојано $a$ потичу од полугласника.

Упознавање са граматиком почиње од номинатива, као основне, полазне форме и падежа једног од два основна реченична члана - субјекта. Даје се четрнаест именица, чији ће облици касније послужити као обрасци и за усвајање осталих падежних форми: пет мушког рода брат, батько, товариш, хлопець, край (скреће се пажња да су мушког рода и именице типа Микола, суддя), четири средњег: село, плече, поле, заняття и пет женског рода: сестра, душа, пісня, аудиторія, ніч (скреће се пажња да је жемског рода и именица мати, која се мења по посебном обрасцу) у облицима номинатива једнине и множине. Именице средњег рода IV деклинације не обрађују се на овој етапи учења украјинског језика с обзиром на њихов ограничен број и специфичну промену. Одмах се уводе и придеви, као и личне, присвојне и показне заменице. Кроз вежбања се имплицитно усвајају нека од значења овог падежа (субјекат - вршилац радње Хлопець читає, предикат - Ми студенти, назив особе, предмета: Це Тарас. Ось книжка, идентификација лица Мене звати Олена). Експлицитно се издвајају две функције: субјекта и (именског дела) предиката, уз напомену о разлици између украјинског и српског због одсуства глагола-свезе у именском предикату у првом (Петро студент - Петар је студент). Остала значења дају се имлицитно ( У мене є сестра, Завтра понеділок итд.) и експлицитно (один зошит, два зошити итд.) касније. И код овог и код осталих падежа материјал је распоређен концентрично: представа о свакој гра- матичкој појави се све више продубљује и шири (Балыхина 2007: 99).

Следећи падеж који се обрађује јесте локатив. Иако у односу на остале падеже има веома ограничен број функција (изражавање места и времена), облици локатива, барем када је реч о именицама, лаки су за усвајање - већина именица сва три рода без обзира на тип промене (тврда, мека, мешовита) има исти наставак -i. Наставак -y, који има одређени број именица мушког и средњег рода, такође не представља проблем за усвајање код говорника српског језика: правила његове употребе су једноставна и лака (са изузетком једносложних именица на којима се на овом нивоу не инсистира), а наставак -у, осим тога, наставак је за локатив именица мушког и средњег рода и у српском језику. Најпре имплицитно, а затим и експлицитно усваја се основна функција локатива - месна (жити в Белграді, стояти на полиці итд.), док ће временска бити усвојена касније. Истовремено се студенти упознају са глаголима који захтевају овај облик или се обично употребљавају у конструкцијама с њим (бути, знаходитися, жити, мешкати, працювати, навчатися, займатися итд.), што представља увод у следећу наставну јединицу - облике презента, најпре прве, а затим и друге конјугације. На овој етапи обрађују се пре свега глаголи код којих нема алтернација последњег сугласника или самогласника унутар основе или они код којих се одговарајуће алтернације срећу и у српском језику.

У даљем редоследу падежа донекле се одступа не само од традиционалног распореда већ и од оног који је уобичајен у новијим методикама и уџбеницима 3 , односно генитив и акузатив се обрађују после инструментала и датива. Разлога за ово одступање има више. С једне стране, примењује се принцип „од лакшег ка тежем" због комплексности правила за образовање облика генитива једнине код именица мушког рода, као и облика генитива множине за сва три рода (који су, за разлику од датива, инструментала, локатива и делом номинатива множине диференцира-

\footnotetext{
${ }_{3}^{3}$ Упоредити, на пример, редослед који предлаже М. Џура, који се базира пре свега на принципу „од лакшег ка тежем”, односно од падежа који имају мање функција ка онима који их имају више (Джура 2007: 197-198)
} 
ни по родовима, а тиме и тежи за усвајање). Акузатив, чији се облици код именица које означавају живо подударају с генитивом у украјинском језику, за разлику од српског, и у једнини и у множини, логично се обрађује после генитива. С друге стране, сродност украјинског и српског језика омогућава имплицитно обрађивање и интуитивно усвајање оних форми ових падежа које су блиске у овим језицима (генитив и акузатив једнине анимантних именица мушког рода брата, генитив и акузатив једнине именица средњег рода села и село, акузатив једнине именица женског рода книгу, любов) у оним функцијама које се подударају (посесивни генитив міста України, акузатив директног објекта бачити друга, читати книгу) или су фреквентне и неопходне за што ранији развој говорних умења (припадност лицу: У мене $\epsilon$ сес$m p a)$. Најзад, облици инструментала неопходни су студентима за прве теме које се обрађују на часовима говорних вежби, као што су упознавање, разговор о себи, о породици и сл. (знайомитися 3 ким, вітатися з ким, розмовляти (володіти) якою мовою, жити де і з ким, займатися чим, цікавитися чим, працювати ким итд.). Од значења инструментала на овој етапи се усвајају социјативно (жити з батьками), атрибутско (чай з цукром, кава з молоком), те значења оруђа и средства (писати ручкою, їхати трамваєм), индиректног објекта (користуватися словником) и именског дела предиката (бути, стати перекладачем).

Будући да датив има мањи број функција од инструментала, иако је лакши за усвајање (наставци једнине за сва три рода се практично потпуно подударају са српским наставцима), обрађује се после инструментала. Од функција овог падежа експлицитно се обрађује само значење адресата (купити дочці), као и конструкције за изражавање узраста (Ïй 23 роки). У оквиру последњих имплицитно се уводе и облици генитива множине именица мушког рода (25 років). Уз датив се лексички уводе и нови глаголи (meлефонувати, вірити, дарувати и сл.), а затим понављају облици садашњег и обрађују облици прошлог времена.

Приликом обрађивања генитива полази се од облика једнине мушког рода на -а код именица које означавају живо, следи средњи род (код оба имамо подударност са српским језиком), затим женски, облици множине сва три рода и тек на крају се обја- шњавају и усвајају облици једнине мушког рода на $-y$. Градивом нису обухваћена сва правила употребе једног од два наставка генитива једнине мушког рода - $а$ или -y, већ само основна. Од функција генитива најпре се експлицитно обрађују оне које су претходно интуитивно усвајане - посесивни генитив и генитив лица коме нешто припада. Приликом обраде посесивног генитива уводе се и присвојни придеви (творба и промена: зошит Tapaса - Тарасів зошит, книжка Тараса - Тарасова книжка) и указује на различиту фреквентност ових синонимичних средстава у украјинском и српском језику. Експлицитно се обрађује функција генитива у одричним конструкцијама (У мене немає брата. У місті немає театру. Вчора не було заняття), партитивни генитив и генитив количине са бројевима и речима типа скільки, багато, трохи, декілька и сл. (випити води, п'ять зошитів, багато студенток, трохи цукру). Обрађују се и неке предлошко-падешке конструкције с генитивом: предлози без, для, крім, као від и до (залежати від батьків, відрізнятися від інших, готуватися до іспиту, звернутися до лікаря), док су просторно и временско значење остављена за касније.

Акузатив се обрађује последњи и усваја релативно брзо с обзиром на то да су студенти већ имплицитно, како кроз позитиван трансфер из матерњег језика, тако и кроз различита вежбања и текстове, већ савладали облике једнине. Од функција акценат је на такође имплицитно обрађеној функцији директног објекта и функцији индиректног објекта у конструкцијама с предлогом про. Када је реч о функцији директног објекта, паралелно са акузативом у потврдним обрађује се и генитив у одричним реченицама (Я не бачив цього фільму), а при обради индиректног лексички се уводе нови глаголи (думати, забувати, мріяти и сл.), након ћега се приступа обнављају форми садашњег времена уз проширење градива облицима у којима долази до различитих алтернација (свистати - свищу, берегти - бережу, вести - веду, ходити - ходжу, ловити - ловлю, брати - беру, лити - ллю, сісти - сяду, взяти - візьму) и атематским глаголима (дати, їсти, відnовісти), као и обради облика будућег времена. Обрада ове граматичке јединице подудара се са обрадом теме Мој дан на говорним вежбама, у оквиру које се имплицитно обрађује још једна 
од функција локатива и генитива - временска (о котрій годині, 3 першої до другої години).

Овај део градива, усмерен од форме ка значењима, завршава се обрадом облика компаратива, који се, будући да су претходно савладани сви падежни облици, одмах уводи у конструкције (вищий від брата - вищий за брата - вищий, ніж брат). Истовремено студенти у оквиру часова говорних вежбања обрађују тему Опис човека (карактер и изглед), где употребљавају велик број придева.

Други део градива, коме се приступа након усвајања свих горепоменутих облика ${ }^{4}$ усмерен је од значења ка средствима њиховог изражавања и обухвата просторне односе, изражавање времена, објекта и адресата. Начин обраде градива илустроваћемо на примеру значењског комплекса просторних односа. Студентима се најпре указује на разлику семантике места и правца, указује се на то да једни те исти предлози али са различитим падежима учествују у конструкцијама којима се изражава место (знаходитися в університеті, на факультеті, перед будинком, за будинком, між будинками, над ліжком, під ліжком) и правац (іти в університет, на факультет, вийти перед будинок, зайти за будинок, між будинки, повісити над ліжко, сховати під ліжко). Студентима се скреће пажња на разлике у употреби предлога в(y) и на у украјинском и српском (у домовини - на батьківщині, на планини - у горах). Даље се указује на разлику изражавања оријентира адлативног кретања и аблативног кретања, односно употребу конструкција с предлозима 3, від, 3-nid, 3-над, 3-за, као и на разлике у употреби предлошко-падешких конструкција када је оријентир представљен анимантном или инанимантном именицом (іти в театр (до театру) и іти до брата, бути в театрі и бути у брата, повернутися з театру и повернутися від брата). Лексички се уводе основни глаголи кретања imu/ходumu, їхатu/ їздити, као и глаголи каузације кретања и положаја у простору

${ }^{4}$ Овде ваља нагласити да се усвајају облици који се могу образовати на основу најопштијих граматичких правила, док се мање фреквентне или нерегуларне форме обрађују само код најучесталијих речи које улазе у лексички минимум, то су рецимо облици множине именица людина, дитина, друг, око, плече, гість, гроші, облици глагола жити, хотіти, пити, підняти, іти, лягти, суплетивни облици компаратива итд. ставити/поставити, стояти, класти/покласти, лежати, вішаmu/повісити, висіти. Поред наведених конструкција обрађују се и конструкције с предлозима по (овде се указује и на форму локатива једнине свих именица мушког и средњег рода на -у уз овај предлог), біля, коло, мимо. Најзад, имплицитно се уводе и друга средства изражавања просторних односа: упитне заменице куди, де, звідки и заменички прилози туди, сюди, там, тут, звідти, звідси, прилози далеко, близько, вгору, вгорі, вниз, внизу, додому, водма.

Овакав начин организације градива показао се као најефикаснији. Комбинација неколико принципа уз коришћење позитивног трансфера (захваљујући генетској сродности украјинског и српског језика) омогућава студнетима не само лако и релативно брзо усвајање основних граматичких облика већ и њихову правилну употребу у комуникацији на почетној етапи учења украјинског језика.

\section{ЦИТИРАНА ЛИТЕРАТУРА}

Балыхина, Т. М. Методика преподавания русского языка как неродного (нового): Учебное пособие для преподавателей и студентов. Москва: Изд-во Российского университета дружбы народов, 2007.

Джура, М. „Порівняльно-зіставний аналіз у вивченні категорії відмінка“. Теорія і практика викладання української мови як іноземної. Вип. 2. (2007): С. 195-200.

Зайченко, Н. Воробйова, С. (укл.) Навчальні мінімуми з української та російської мов для іноземців. Київ: Інститут системних досліджень освіти, 1995.

Кончаревић, К. Савремена настава руског језика: садржаји, организација, облици. Београд: Славистичко друштво Србије, 2004.

Мацюк, 3. „Лінгвістичні основи методики викладання граматики української мови як іноземної“. Теорія і практика викладання української мови як іноземної. Вип. 2. (2007): С. 31-39.

Ніколаєва, Н. Бондарєва Н. Дем'янюк А. Шевченко М. Овдіюк В.Якубовська М. (укл.). Стандарт з української мови якіноземної. Початковий рівень (A 1). <http://old.mon.gov.ua/ua/activity/education/1410876247/ $>06.09 .2017$. 
Ніколаєва, Н. Бондарєва Н. Дем'янюк А. Шевченко М. Овдіюк В. Якубовська М. (укл.). Стандарт з української мови як іноземної. Базовий рівень (А 2). <http://old.mon.gov.ua/ua/activity/education/1410876247/ $>06.09 .2017$.

\section{ПРИНЦИПЫ ОРГАНИЗАЦИИ ГРАММАТИЧЕСКОГО МАТЕРИАЛА В ПРЕПОДАВАНИИ ГРАММАТИКИ УКРАИНСКОГО ЯЗЫКА} НА НАЧАЛЬНОМ УРОВНЕ

Изучение иностранного языка имеет несколько аспектов. Одним из них является грамматика: знание грамматических форм и их функций необходимо как для лучшего понимания устной или письменной речи, так и для правильного составления высказываний. Вопросы о подходе к изучению грамматики украинского языка как иностранного, особенно в инославянской аудитории, не были предметом широкого интересованния методистов. Цель нашей работы - представить одну из возможностей методической организации грамматического материала в преподавании украинского языка на начальном уровне. Речь идет о такой организации материала, которая основывается на функциональном принципе, объединяющем семасиологический и ономасиологический подходы. Такой подход предусматривает ознакомление студентов с грамматическими формами и их основными функциями, идя от формы к значению на первом этапе изучения украинского языка, в то время как на втором этапе усвоенные формы повторяются и устанавливаются, идя от комплекса различных значений (значения места и направления, времени, объекта, адресата и т.д.) к падежным и предложно-падежным формам, формулирующим их значение, с введением других средств (наречий, местоимений) Вторым важным принципом организации грамматического материала является основной методологический принцип „от более легкого к более трудному”. Этот принцип в данном случае предусматривает как отступление от традиционального порядка изучения падежей (именительный - родительный дательный - винительный - творительный - предложный - звательный), так и порядка, принятого в новых методиках и учебниках (именительный - предложный - винительный - родительный - творительный - дательный - звательный) с целью постепенного использования форм, которые студенту необходимо усвоить. В таком порядке (именительный - предложный - творительный -дательный - родительный - винительный - звательный) родительный падеж, например, хотя и является формой, выполняющей множество различных функций, дается, учитывая большой выбор окончаний и сложные правила их употребления, только после дательного падежа, падежа со значительно меньшим количеством функций. Винительный, хотя и является центральным падежом в украинской системе падежей и сравнительно легким для восприя- тия носителями сербского языка, рассматривается после родительного падежа, поскольку в большинстве имен существительных его формы совпадаю' именно с родительным или именительным падежом. Третий принцип организации грамматического материала можно охарактеризовать как комму никативный. Преподавание грамматики неотделимо от изучения лексики, а коммуникативная ориентация преподавания предполагает акцентирование внимания студента не только на формы и их значения, но и на употребление усвоенных форм в коммуникации. Распределение грамматического материала в этом смысле должно соответствовать порядку изучения новой лексики и разговорных тем, рассматриваемых в рамках начального курса современного украинского языка. 